Bull. Fac. Agric., Cairo Univ., 69:353-369 (2018).

\title{
CORRELATION BETWEEN DOUGH RHEOLOGICAL PROPERTIES AND PAN BREAD CRUMB QUALITY CHARACTERISTICS
}

\author{
(Received: 19.10.2018)
}

\author{
By \\ M. H. Abd-El-Khalek and M. R. G. Youssif \\ Food Technology Research Institute, Agricultural Research Center, Giza, Egypt
}

\begin{abstract}
Dough rheological properties measured by farinograph and extensograph were studied in terms of their correlation with digital image analysis (DIA) and texture profile analysis (TPA) characteristics of pan bread crumb. Incorporation of corn starch at different levels led to variations in rheological properties of the studied pan bread doughs. The results showed that most dough rheological properties had strong correlation with bread crumb characteristics. DIA results, revealed that most of farinograph properties were found to be highly correlated (positively or negatively)to cell no., average cell size, cell and wall areas of bread crumb. The same DIA parameters also correlated to maximum resistance to extension and proportional number as determined by the extensograph. Bread crumb specific volume was highly correlated to all the studied farinograph and extensograph parameters. TPA showed that hardness of bread crumb was significantly correlated with all the studied farinograph parameters except for development time. Concerning extensograph parameters, high correlation was observed between maximum resistance to extension, proportional number and energy,and the hardness of pan bread crumb. Springiness was the only TPA parameter that exhibited a high correlation with all the studied farinograph and extensograph properties.
\end{abstract}

Key words: bread crumb, rheology, digital image analysis, texture profile analysis, correlation.

\section{INTRODUCTION}

Dough rheological properties have a very important role in determining the processing, handling and the quality of bakery products in general, and bread in particular (McCann et al., 2016). The quality of bread could be a result of dough rheological properties along with the gas cell structure (Nindjin et al., 2011). Bread dough has a viscoelastic behavior which combines the properties of viscous fluids and elastic solids. Flour and water are the key ingredients that form together the dough, and play a significant role in defining the rheological and structural properties of dough, and consequently the quality of resultant bread (Upadhyay et al., 2012).

Bread quality depends on many variables such as gluten content and quality of the flour, bread volume, crumb properties and texture (Sapirstein, et al., 1994; Upadhyay et al., 2012). Gas bubbles, initially are introduced into the dough during the mixing and form the gas cells in bread crumb. The number and size of the gas cells can vary and lead to huge differences in bread crumb grain quality and texture (Scanlon and Zghal, 2001).

Gluten is the major protein in wheat flour, and is responsible for the unique viscoelastic behavior of wheat flour doughs and their ability to retain gas during proofing and baking procedures as well (Dobraszczyk, 2003). Dough consists of a complex structure of protein and carbohydrates cross-links which determine their rheological behavior (Abang Zaidel et al., 2010).

Bread quality was found to be in good correlation with the rheological properties of wheat flour (Autio et al., 2001). Among different empirical rheological methods, farinograph and extensograph are the most important and widely used (Tietze et al., 2016). Bread crumb is a solidlike material that doesn't show proportional stress to a given strain out of its linear viscoelastic region (Angioloni and Collar, 2009). Uthayakumaran et al., (2002) reported that starch addition to gluten 
starch mixtures affected the strain hardening of gluten-starch mixture.

Recently, the analysis of digital images is broadly used for the evaluation of bread crumb grain and is suitable to the assessment of bread cut image texture (Švec and Hrušková, 2004). An instrumental technique has been developed for the evaluation of crumb grain by the use of image analysis technology that could be implemented using a personal computer (Sapirstein et al., 1994). The software used for this purpose has been developed by several researchers using multiple algorithms from cell segmentation techniques with the aim of determining the size and shape distribution of bread crumb cells (Pa et al., 2013). Digital image analysis could be a potential for the objective measurements of bread crumb, and it has been recommended as a tool to assess crumb characteristics such as cell size, number per area unit, distribution, area and wall thickness (Sapirstein, 1999; Zghal et al, 1999; Lagrain et al., 2006; Farrera-Rebollo et al., 2012).

Textural properties are of the key factors that determine consumer satisfaction and acceptance of the pan bread (Angioloni and Collar, 2009). Flour strength was found to have a major impact on bread crumb properties including finer, more uniform crumb grain, stronger and more extensible bread crumb, and consequently fewer crumb defects (Zghal et al.,2001).

The present work was undertaken to better understand the correlation between dough rheological properties and the quality characteristics of pan bread crumb as determined by the use of digital image analysis (DIA) technique, and textural profile analysis (TPA) as determined by Brookfield CT3 Texture Analyzer.

\subsection{Materials}

\section{MATERIALS AND METHODS}

Wheat flour (72\% extraction rate) was obtained from Five Star Flour Mills Company, Suez, Egypt. Food grade edible corn starch was obtained from the Egyptian Starch and Glucose Co., Cairo, Egypt. Instant active dry yeast (Saccharomyces cerevisiae), sugar (sucrose), margarine, salt and skim milk powder were obtained from the local market.

\subsection{Methods}

\subsubsection{Preparation of composite flours}

In order to obtain bread samples with different rheological properties with the aim of investigating the correlation between dough rheological properties and bread crumb quality, corn starch was used to substitute wheat flour at levels of 0 (control), 20, 40, 60 and 80\% (flour weight basis).

\subsubsection{Gluten determinations}

Wet and dry gluten and gluten index of wheat flour were determined by using Glutomatic perten instruments (AB type 2200 No. 005092, Huddling, Sweden) as described by Perten (1990). Gluten index was calculated according to the following equation:

Gluten index $=\frac{\text { Remained gluten on cassette }}{\text { Total gluten }} \times 100$

\subsubsection{Farinograph test}

Farinograph instrument (Brabende Duis Bur G, type 810105001 No. 941026 , West Germany) was used to determine the water absorption and mixing characteristics of doughs prepared from the various studied blends. Farinogram parameters (i.e. arrival time (AT), dough development time(DDT), dough stability time (DST), mixing tolerance index(MTI) and degree of softening (DS)were obtained from the farinograms except the percentage of water absorption (WA) which was recorded directly from the farinograph burette as described in the A.A.C.C. (2010).

\subsubsection{Extensograph test}

Extensograph tests were carried out according to the method described in the A.A.C.C (2010) by usingExtensograph (Barabender Duis Bur G type 860001 No. 946003 , West Germany), to obtain the dough maximum resistance to extension ( $\mathrm{R}$, Elasticity), dough extensibility (E), proportional number (R/E)and dough energy (E).

\subsubsection{Processing of pan bread}

Pan bread was processed according to the method of A.A.C.C. (2010). The formulas used for the preparation of pan bread are shown in Table (1).All ingredients were mixed together in a "300 $\mathrm{g}$ flour'farinograph mixing bowl until they reached maximum development., then they were let to rest for $20 \mathrm{~min}$ at $28-30^{\circ} \mathrm{C}$ (first proofing) followed by dividing doughs into three $150 \mathrm{~g}$ pieces, moulded by hand and put into pans $(13 \times 8$ $\mathrm{x} 7 \mathrm{~cm}$ ) for final proofing at $32-35^{\circ} \mathrm{C}$ and $80-85 \%$ relative humidity in fermentation cabinet for 60 min. Doughs were then baked in electrically heated oven with steam added during baking at $210-220^{\circ} \mathrm{C}$ for $15-20 \mathrm{~min}$. After baking, loaves 
were separated from the metal pan and allowed to cool at room temperature before being sealed in polyethylene bags to prevent moisture loss and then stored at room temperature $\left(18 \pm 2^{\circ} \mathrm{C}\right)$. was measured and the specific volume was calculated according to the following equation:

Crumb specific volume $\left(\mathrm{CSV}, \mathrm{cm}^{3} / \mathrm{g}\right)=$ cube length $(\mathrm{cm}) \times$ width $(\mathrm{cm}) \times$ height $(\mathrm{cm})$

Table (1): Formulas for pan bread samples (100 $\mathrm{g}$ flour basis).

\begin{tabular}{|c|c|c|c|c|c|c|c|c|}
\hline Sample & $\begin{array}{c}\text { Wheat } \\
\text { flour } \\
\text { (g) }\end{array}$ & $\begin{array}{l}\text { Corn } \\
\text { starch } \\
\quad(g)\end{array}$ & $\begin{array}{c}\text { Sugar } \\
(\mathrm{g})\end{array}$ & $\begin{array}{c}\text { Fat } \\
\text { (margarine) } \\
(\mathrm{g})\end{array}$ & $\begin{array}{c}\text { Skim } \\
\text { milk } \\
\text { powder } \\
\text { (g) }\end{array}$ & $\begin{array}{c}\text { Salt } \\
\text { (g) }\end{array}$ & $\begin{array}{c}\text { Instant } \\
\text { active } \\
\text { dry yeast } \\
\text { (g) }\end{array}$ & $\begin{array}{c}\text { Water } \\
(\mathbf{m l})\end{array}$ \\
\hline Control & 100 & - & 5 & 4 & 2 & 1 & 1.8 & \multirow{5}{*}{ 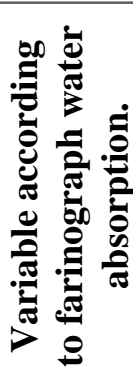 } \\
\hline CS20 & 80 & 20 & 5 & 4 & 2 & 1 & 1.8 & \\
\hline CS40 & 60 & 40 & 5 & 4 & 2 & 1 & 1.8 & \\
\hline CS60 & 40 & 60 & 5 & 4 & 2 & 1 & 1.8 & \\
\hline CS80 & 20 & 80 & 5 & 4 & 2 & 1 & 1.8 & \\
\hline
\end{tabular}

\subsubsection{Digital image analysis}

For the assessment of breadcrumb quality by using the digital image analysis (DIA), the method of Magdic et al. (2006) with some modifications was used. Bread loaves were sliced in the middle providing two cross sections. Slices were scanned by using CanonScan LIDE100 Scanner (Angioloni and Collar, 2009) and the images were saved as JPEG files with a resolution of $600 \mathrm{dpi}$. An area of $5 \times 5 \mathrm{~cm}(50$ pixels $/ \mathrm{cm})$ was cropped from the middle of the slice for further assessments. The images were then adjusted and the threshold tool was applied to obtain the binary images by Image ${ }^{\circledR}$ software. After image preprocessing, evaluation of crumb texture appearance was performed and the following readings were recorded: cell count, maximum cell area, minimum cell area, average cell size, total cells area (\%), walls area (\%) and SD for cell areas.

\subsubsection{Bread crumb specific volume}

Specific volume of bread crumb was determined according to the method of Villarino et al. (2015) as follows:

A cube from the center of a pan bread loaf was carefully cut (within $24 \mathrm{~h}$ of baking) to avoid the deformation of crumb by using a sharp knife. Length, width and height of the cube were measured by using a caliper. Weight of the cube

\subsubsection{Texture profile analysis (TPA)}

For the analysis of the texture of bread crumb samples, Brookfield CT3 instrument (Brookfield Engineering Laboratories, Inc., MA 02346-1031, USA) was set with a TA-AACC 36 probe and was used to determine texture profile analysis of bread crumb according to the methodoutlined in the A.A.C.C. (2010) as follows:

One slice of bread (approximately $25 \mathrm{~mm}$ ) was cut by a hand knife; three end slices were discarded while the crusts were not removed. A $36 \mathrm{~mm} \varnothing$ probe was set at a test speed of $2 \mathrm{~mm} / \mathrm{s}$. Testing was located in the centre of the bread slice avoiding non-representative areas of crumb. Samples were subjected to $40 \%$ deformation and the compression load at $25 \%$. Deformation was recorded in Newtons and the following characteristics were determined: hardness (cycle 1), hardness (cycle 2), cohesiveness, adhesiveness, springiness, springiness index and chewiness as described in the operating instruction manual.

\subsubsection{Statistical analysis}

The obtained data were statistically analyzed by the Analysis of Variance using General Linear Model (GLM) procedure within a package program of Statistical Analysis System (SAS, 1987). Pearson's correlation coefficient and the 
significance of correlation at confidence levels of 95 and $90 \%(\alpha=0.05,0.1)$ were determined by using Microsoft Office Excel software. The obtained results of correlation coefficient were interpreted and ranked according to the scale described by Zou et al.(2003) as shown in Table (2).

Table (2): Interpretation of correlation coefficient (strength and direction).*

\begin{tabular}{|c|c|c|}
\hline $\begin{array}{c}\text { Correlation } \\
\text { Coefficient } \\
\text { value }\end{array}$ & Strength & Direction \\
\hline 1 & Perfect & Positive \\
\hline $\mathbf{0 . 8}$ to $-\mathbf{0 . 9 9}$ & Strong & Positive \\
\hline $\mathbf{0 . 5}$ to 0.79 & Moderate & Positive \\
\hline $\mathbf{0 . 2}$ to 0.49 & Weak & Positive \\
\hline $\mathbf{0}$ to 1.99 & $\begin{array}{c}\text { Very weak or no } \\
\text { correlation }\end{array}$ & Positive \\
\hline-1.9 to 0 & $\begin{array}{c}\text { Very weak or no } \\
\text { correlation }\end{array}$ & Negative \\
\hline $\mathbf{- 0 . 2 ~ t o ~}-0.49$ & weak & Negative \\
\hline $\mathbf{- 0 . 5}$ to -0.79 & Moderate & Negative \\
\hline $\mathbf{- 0 . 8}$ to -0.99 & Strong & Negative \\
\hline$-\mathbf{1}$ & Perfect & Negative \\
\hline
\end{tabular}

* According to Zou et al., (2003).

\section{RESULTS AND DISCUSSION}

In the present study, and in order to obtain bread dough formulations with variable rheological properties, corn starch was added to substitute 20,40, 60 and $80 \%$ of wheat flour used in the processing of pan bread. This trend was previously supported by Nindjin et al. (2011) who concluded that the addition of starch during the mixing phase, to substitute the white wheat flour had a tendency to modify the flour strength from strong to weak due to some factors including the level of substitution.

\subsection{Gluten determinations of experimental bread flour composites}

The effect of corn starch inclusion into bread flour samples at different levels on gluten determinations is depicted in Fig. (1).
The control flour samples were found to have values of 34.98 and $11.80 \%$ of wet and dry gluten, respectively. Incorporation of corn starch led to a decrease in both wet gluten (Fig.1.a) and dry gluten (Fig.1.b). This decrease could be attributed to the dilution of gluten as a consequence of the substitution of wheat flour with corn starch that contains no-gluten-forming proteins (Nindjin et al., 2011).

Gluten index (GI) is the weight of the percentage of wet gluten remaining on a sieve after automatic washing with salt solution and centrifugation as related to total gluten (A.A.C.C. 2010). According to Cubadda et al. (1992), the

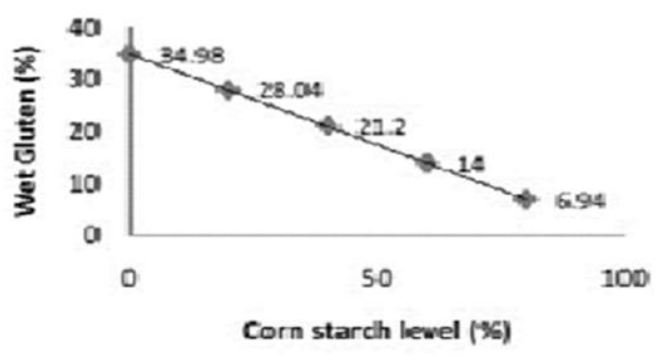

(a)

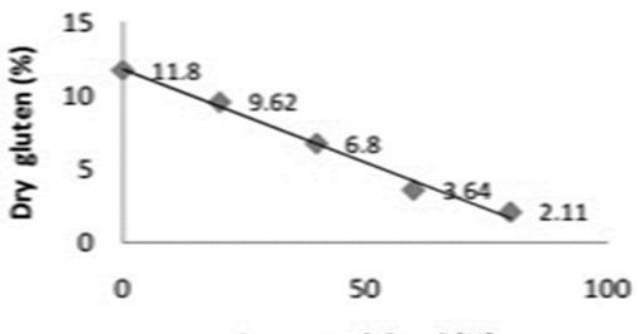

Corn starch level (\%)

(b)

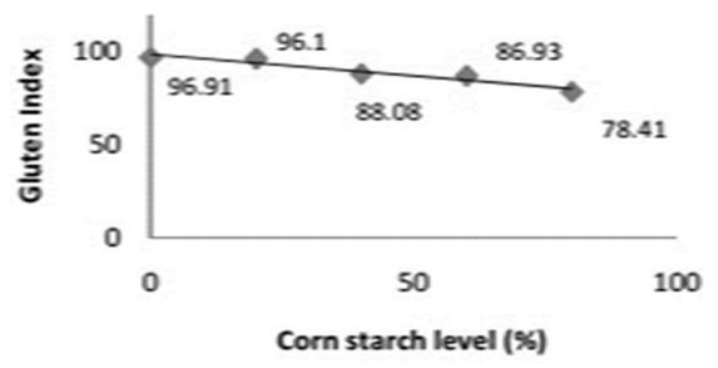

(c)

Fig. (1):Gluten values of the tested bread flour samples*. * (a) Wet gluten, (b) dry gluten, (c) gluten index. 
tested control flour with a gluten index value of 96.91 is categorized as "strong" wheat flour (GI > 80) which is suitable for pan bread processing. As shown in (Fig. 1.c ) GI was decreased from 96.91 in control flour to 78.41 at $80 \%$ starch incorporation level. This comparatively slight decrease in gluten index could be attributed to the loss in gluten due to technical difficulties arose during the extraction of gluten, especially with the inclusion of high levels of starch, rather than a change in gluten quality.

\subsection{Farinograph properties of the experimental bread flour composites}

The farinograms obtained from the farinograph test are shown in Fig. (2). Farinograph parameters which arepresented in Table (3) demonstrated that increasing the starch addition level had a decreasing effect on WA (recorded from the farinograph burette) of flour samples. Flour samples had WA values of 64.3, 62.8, 61.5, 59.4 and $57.7 \%$ for starch addition levels of 0 (control), 20, 40, 60 and $80 \%$. Even though these results differ from an earlier study by Defloor et al. (1993) who reported that no drastic change in WA ranges for the investigated substitutions (with wheat and cassava starches), they are consistent with those of Nindjin et al. (2011) who found that farinograph WA decreased at substitution levels more than $20 \%$ with yam and cassava starches. AT which is the time in minutes required for the curve to reach the 500 B.U line after the mixer had been started through addition of water, was found to decrease from 2 minutes for control flour to 1 minute in flour substitutes with corn starch at $80 \%$ level. The time from the first addition of water to the development of dough maximum consistency (DDT) remained constant (4 min) up to a substitution level of $40 \%$, and then decreased. DST, which is the time in minutes elapsing when the top of the curve intercepts with first 500 B.U line until the curve leaves that line, dramatically decreased from $11.5 \mathrm{~min}$ in control flour to only 1.5 minutes in flour with $80 \%$ starch level. Wang et al. (2002) mentioned that DDT and DST were determinant measurements for the strength of investigated flour. Such influence corresponds with the finding of Ammar et al. (2009) who reported that inclusion of starch in bread formulas had a weakening effect on gluten network. In contrast, both MTI and DS increased with the incorporation of corn starch. Addition of starch, as a non-gluten forming material, led to a weak development of gluten network. This could explain the quick breakdown of gluten network and the weak kneading resistance to the farinograph mixer (Nindjin et al., 2011)

\subsection{Extensograph properties of experimental bread flour composites}

The different readings obtained from extensographcurves are illustrated in Fig. (3). and Table (4). E, which is the total length of the base of the extensogram curve, didn't show a constant trend as it went higher by increasing the starch incorporation level up to $40 \%$ level (from 145 to $165 \mathrm{~mm}$ ), then decreased at 60 and $80 \%$ starch levels to be 108 and $65 \mathrm{~mm}$, respectively. The height of the extensogram curve measured in Barabender units (R) decreased from 960 to 150 BU by the incorporation of corn starch up to $80 \%$ starch level. Proportional number (R/E) had constantly reducing values $(6.62,5.2,3.76,3.7$ and 2.31) associated with the increment of starch levels $(0,20,40,60$ and $80 \%$, respectively). The same trend was noticed concerning energy(the area under the curve measured with planimeter). Extensograph can provide us with several indicators for extension characteristics of flour doughs and therefore the expected bread quality (Chen et al., 2009).

\subsection{Digital Image Analysis(DIA) of pan bread crumb}

Cross sections of the produced pan bread samples indicating the effect of corn starch inclusion at different levels on bread appearance and crumb structure are shown in Fig. (4). The cellular crumb structure of pan bread is an important indicative factor to determine its textural properties (Scheuer et al., 2015), thus threshold digital images of bread crumb are analyzed as shown in Fig.5. and the obtained data were presented in Table (5).

Crumb cell count was decreased as the starch inclusion level increased. The crumb total cell countin the image incase of control bread was 494 and graduallyreduced to 141 cellsin case of bread with $80 \%$ starch substitution level. Contrary to this trend, average cell size was increased from 99 pixels in control bread crumbto 401 pixelsas the starch level increased to $80 \%$. This could be attributed to the changes occurred in dough strength associated with the addition of starch 

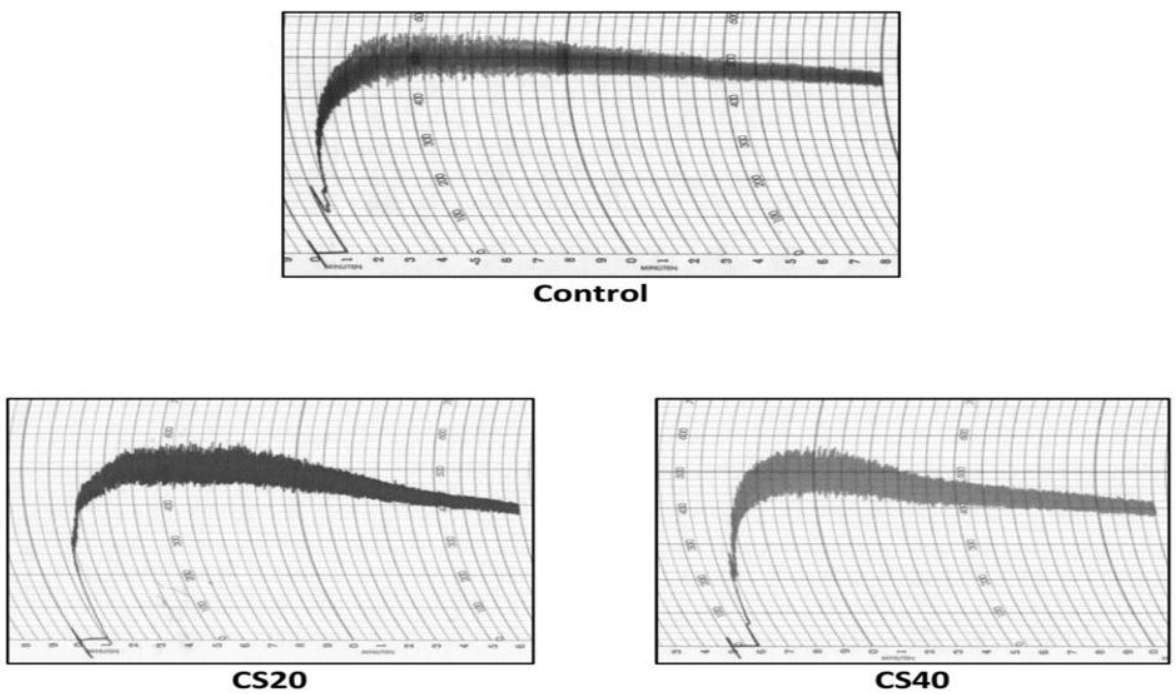

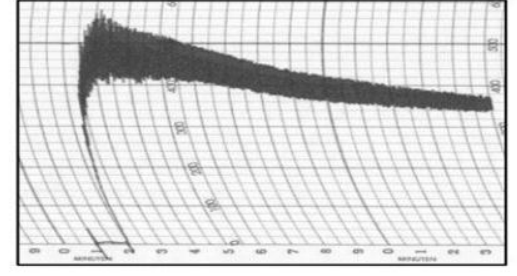

CS60

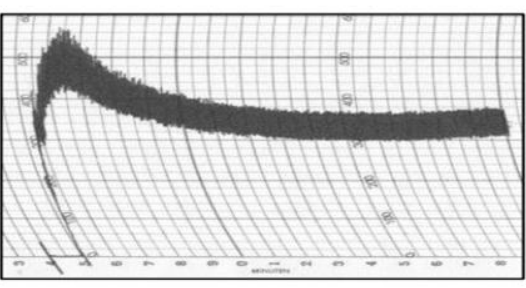

CS80

Fig. (2): Farinograms of tested bread flour samples*.

$*$ Control $=100 \%$ wheat flour,

CS20 $=20 \%$ corn starch $+80 \%$ wheat flour,

$\mathrm{CS} 40=40 \%$ corn starch $+60 \%$ wheat flour,

CS60 $=60 \%$ corn starch $+40 \%$ wheat flour,

CS80 $=80 \%$ corn starch $+20 \%$ wheat flour.

Table (3): Farinogram parameters of bread dough samples*.

\begin{tabular}{|l|c|c|c|c|c|}
\hline & Control & CS20 & CS40 & CS60 & CS80 \\
\hline Water Absorption (\%) & 64.3 & 62.8 & 61.5 & 59.4 & 57.7 \\
\hline Arrival time (min.) & 2 & 3 & 1.5 & 1.5 & 1 \\
\hline Development time (min.) & 4 & 4 & 4 & 2 & 1.5 \\
\hline Dough stability (min.) & 11.5 & 8.5 & 5.5 & 3 & 1.5 \\
\hline Mixing tolerance index ( B.U.) & 20 & 40 & 80 & 110 & 170 \\
\hline Degree of softening (B.U.) & 30 & 80 & 100 & 140 & 160 \\
\hline
\end{tabular}

$*$ Control $=100 \%$ wheat flour,

CS20 $=20 \%$ corn starch $+80 \%$ wheat flour,

CS40 $=40 \%$ corn starch $+60 \%$ wheat flour,

CS60 $=60 \%$ corn starch $+40 \%$ wheat flour,

$\mathrm{CS} 80=80 \%$ corn starch $+20 \%$ wheat flour. 


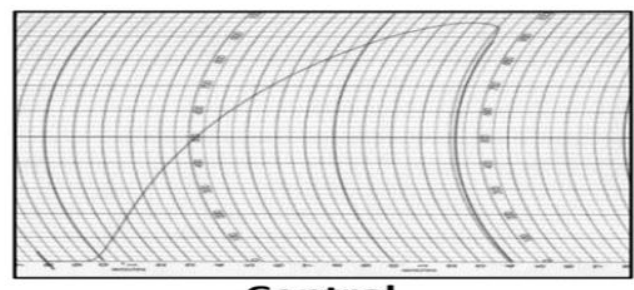

Control

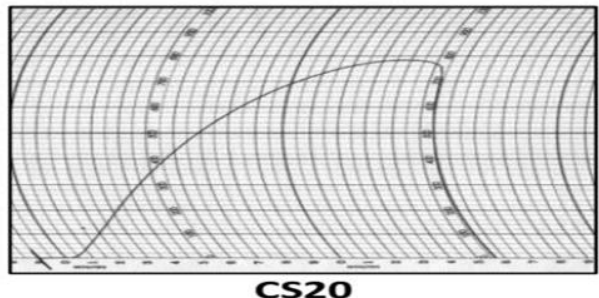

CS20

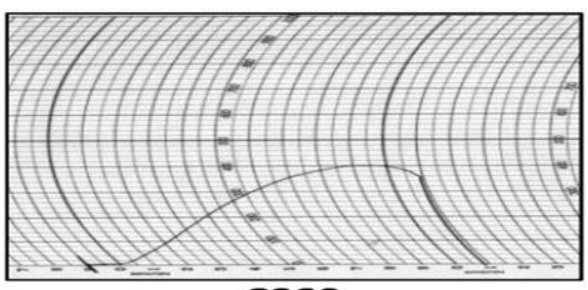

CS60

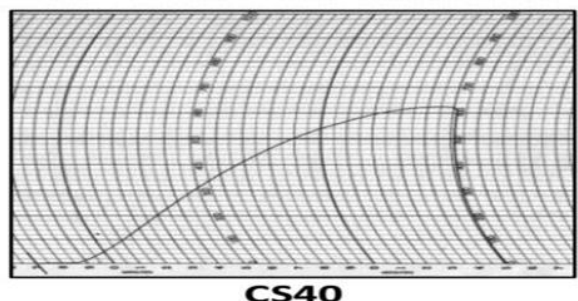

CS40

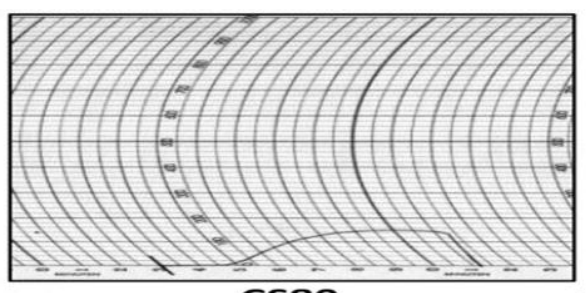

C580

Fig. (3): Extensograms of tested bread flour samples.

$*$ Control $=100 \%$ wheat flour,

CS20 $=20 \%$ corn starch $+80 \%$ wheat flour,

CS60 $=60 \%$ corn starch $+40 \%$ wheat flour,

CS40 $=40 \%$ corn starch $+60 \%$ wheat flour, CS80 $=80 \%$ corn starch $+20 \%$ wheat flour

Table (4): Extensogram parameters of bread dough samples*.

\begin{tabular}{|l|c|c|c|c|c|}
\hline & Control & CS20 & CS40 & CS60 & CS80 \\
\hline Maximum resistance to extension "R" (BU) & $\mathbf{9 6 0}$ & $\mathbf{7 8 0}$ & $\mathbf{6 2 0}$ & $\mathbf{4 0 0}$ & $\mathbf{1 5 0}$ \\
\hline Extensibility “E” (mm) & $\mathbf{1 4 5}$ & $\mathbf{1 5 0}$ & $\mathbf{1 6 5}$ & $\mathbf{1 0 8}$ & $\mathbf{6 5}$ \\
\hline Proportional number (R/E) & $\mathbf{6 . 6 2}$ & $\mathbf{5 . 2}$ & $\mathbf{3 . 7 6}$ & $\mathbf{3 . 7}$ & $\mathbf{2 . 3 1}$ \\
\hline Energy $\left(\mathbf{c m}^{2}\right)$ & $\mathbf{2 1 0}$ & $\mathbf{1 9 2}$ & $\mathbf{1 4 8}$ & $\mathbf{7 0}$ & $\mathbf{1 7}$ \\
\hline $\begin{array}{l}\text { * Control = 100\% wheat flour, } \\
\text { CS40 = 40\% corn starch+ 60\% wheat flour, }\end{array}$ & CS60 $=60 \%$ corn starch $+80 \%$ wheat flour, \\
\end{tabular}






Fig. (4): Cross sections of experimental breads.

* control $=100 \%$ wheat flour,

CS20 $=20 \%$ corn starch $+80 \%$ wheat flour,

CS $40=40 \%$ com starch $+60 \%$ wheat flour,

CS60 $=60 \%$ corn starch $+40 \%$ wheat flour,

CS80 $=80 \%$ corn starch $+20 \%$ wheat flour,

Table (5): Digital image analysis of bread crumb samples*.

\begin{tabular}{|c|c|c|c|c|c|}
\hline & Control & CS20 & CS40 & CS60 & CS80 \\
\cline { 2 - 6 } Cell no. & 494 & 394 & 449 & 258 & 141 \\
\hline Average Cell Size (pix) & 99 & 131 & 121 & 200 & 401 \\
\hline Cells Area (\%) & 39.12 & 41.23 & 43.55 & 41.18 & 45.13 \\
\hline Walls Area (\%) & 60.88 & 58.77 & 56.45 & 58.82 & 54.87 \\
\hline Min. cell size (pix) & 1 & 1 & 1 & 1 & 1 \\
\hline Max. cell size (pix) & 17109 & 9412 & 5661 & 11640 & 11687 \\
\hline Cell Size SD & 8019.86 & 658.24 & 502.40 & 958.29 & 1788.12 \\
\hline
\end{tabular}

$*$ Control $=100 \%$ wheat flour,

CS20 $=20 \%$ corn starch $+80 \%$ wheat flour,

CS40 $=40 \%$ corn starch $+60 \%$ wheat flour,

CS60 $=60 \%$ corn starch $+40 \%$ wheat flour,

CS80 $=80 \%$ corn starch $+20 \%$ wheat flour.

which led to the production of doughs with weaker gluten network,in which small air bubbles tended to coalesce into larger ones and consequently bigger gas cells are formed (Sapirstein et al.,1994). The percentage of cell area had the same increasing behavior (from 39.1 to $45.1 \%$ ).
Because of the limited ability of the digital image analysis software in the detection of small crumb cells under the experimental image resolution, cells with a size of less than 1 pixel were not included in our study. On the other hand, maximum cell size was variable between the bread 


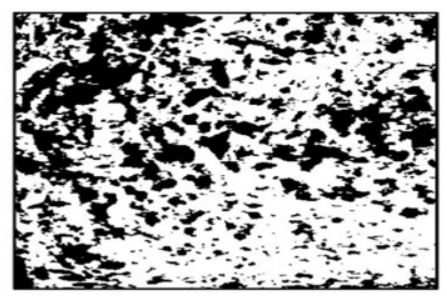

Control

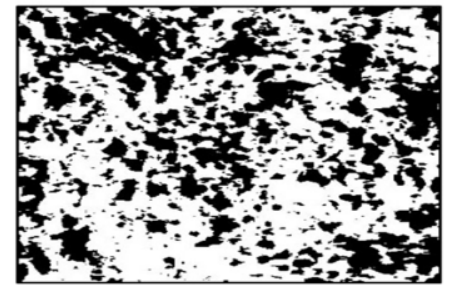

CS2O

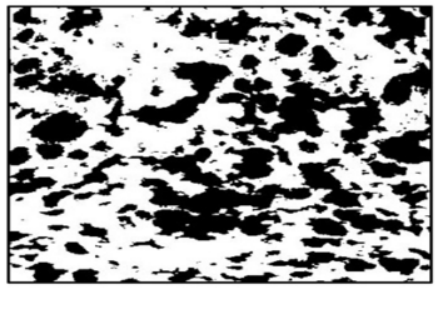

CS60

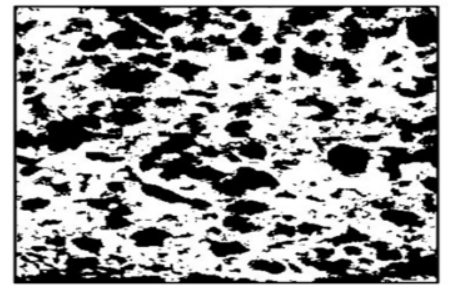

CS40

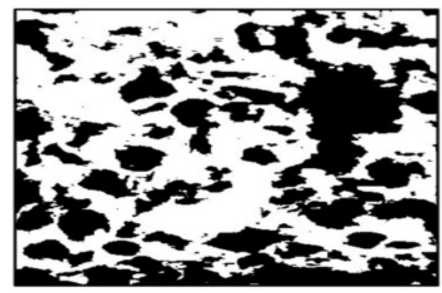

CS80

Fig. (5): threshold digital images of tested bread crumb samples.

$*$ control $=100 \%$ wheat flour,

CS40 $=40 \%$ com starch $+60 \%$ wheat flour,

CS80 $=80 \%$ corn starch $+20 \%$ wheat flour.

crumb samples without a clear particular trend. This result is consistent with those of Scanlon and Zghal. (2001) who pointed out that bread crumb is characterized by a non-uniform structure which comprises a wide distribution of cell sizes resulting in regions with different numbers of small and large cells.

\subsection{Specific volume of pan bread crumb}

The effect of the addition of corn starch on the specific volume of resultant pan bread crumbs is shown in Fig. (6). Inclusion of corn starch resulted in more dense bread crumbs with lower specific volume. This decrease could be explained by the low ability of gluten network to enclose the carbon dioxide produced during fermentation and provides a dense bread texture (Yesli et al., 2017).
CS20 $=20 \%$ corn starch $+80 \%$ wheat flour, CS60 $=60 \%$ corn starch $+40 \%$ wheat flour,

\subsection{Texture Profile Analysis of pan bread crumb}

Texture profile analysis (TPA) diagrams are shown in Fig. (7). and the obtained TPA data are presented in Table (6). Hardness is represented as thepeak force of the first compression cycle. Incorporation of corn starch into bread formulations at levels of $(0,20,40,60$ and $80 \%)$ led to harder crumb $(8.85,10.31,13.85,12.66$ and $20.16 \mathrm{~N}$, respectively) in the firstcycle of deformation. The increase in hardness could be attributed to the inclusion of corn starch and its contribution to amylose and amylopectin matrix (Schiraldi and Fessas, 2000). Also, the increase in hardness could be a result of the decrease in bread crumb specific volume as previously mentioned in 
Fig. (6). Cohesiveness (the ratio of the work during compression of the second cycle divided by that of the first cycle), adhesiveness (the negative area for the first bite, representing the work necessary to pull the compressing plunger away from the sample) and chewiness (the product of hardness, cohesiveness and springiness) did not show a particular trend.

Springiness values $(2.23,2.44,2.72,3.55,4.15$ $\mathrm{mm})$ and springiness index $(0.45,0.49,0.55,0.71$ and 0.83 ) increased as the level of incorporated starch increased $(0,20,40,60$ and $80 \%$, respectively). Feili et al. (2013) attributed the increase in springiness to the dilution of gluten structure in composite bread.

\subsection{Correlation between dough rheological properties and bread crumb digital image characteristic}

The correlations between dough rheological properties determined by farinograph and digital image analysis characteristics of pan bread are shown in Table (7). For WA, it had a strong positive correlation with cell no. and the percentage of walls area, while this relationship was negative with both average cell size and percentage of cells area. Cell no. was positively correlated with both AT and DDT, while negative in case of DST, MTI and DS. Average cell size was negatively correlated with WA, AT, DST and DDT, and positively with MTI and DS. Cells area $\%$ were negatively correlated to WA, AT, DDT and DST, and positively withMTI and DS. These results are in agreement with those of Zghal et al. (2001) who concluded that stronger doughs have greater rates of strain hardening due to the orientation of the glutenin macropolymer. As a consequence, dough's cell walls become more stabilized against rupture, and thus a more uniform crumb grain formed. Significance of correlation was not applicable for minimum cell area as the values obtained were constant at the value of 1 pixel (the minimum detected area by the image analysis software).

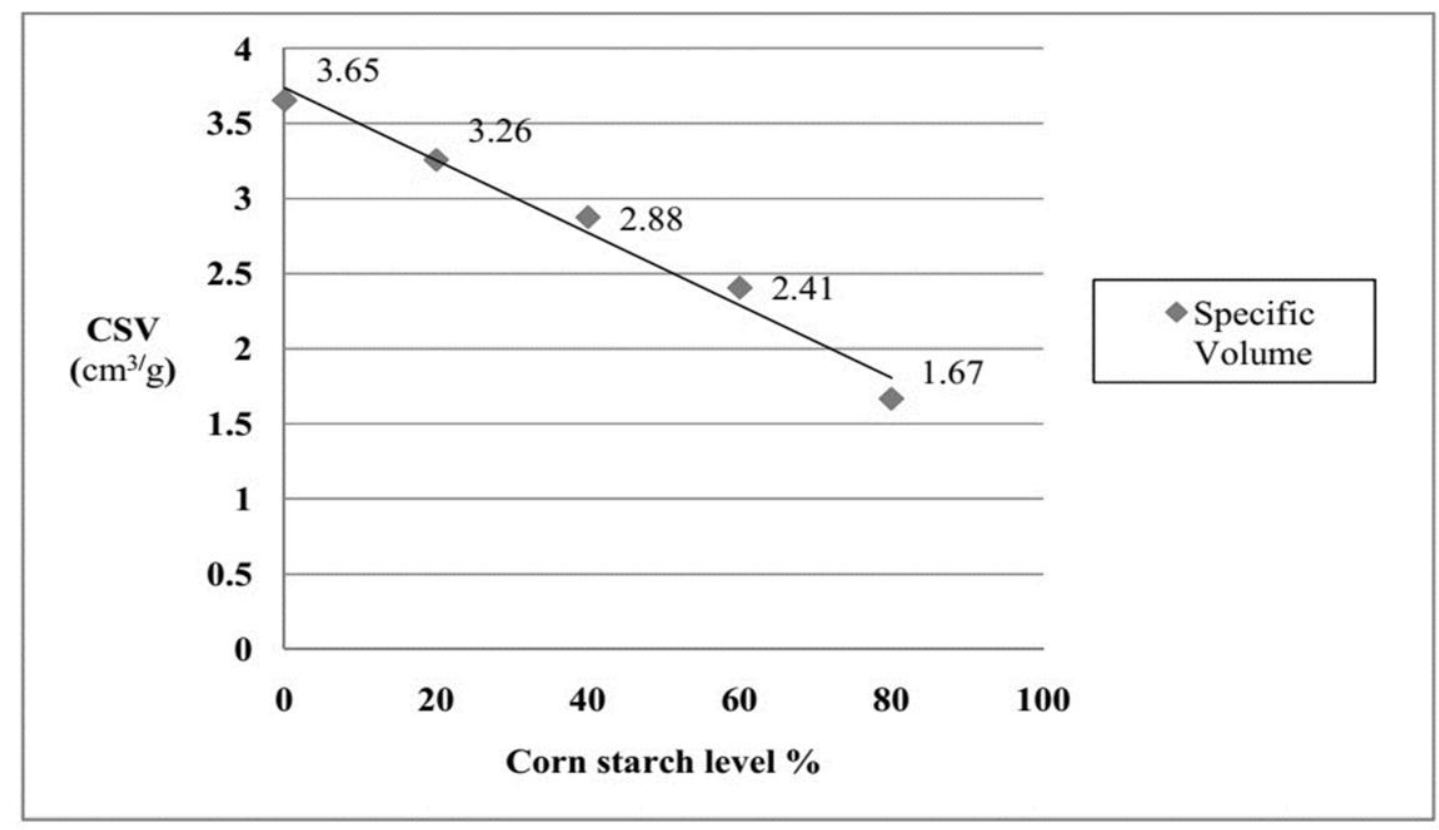

Fig. (6): Crumb specific volume (CSV) of tested bread crumb samples. 


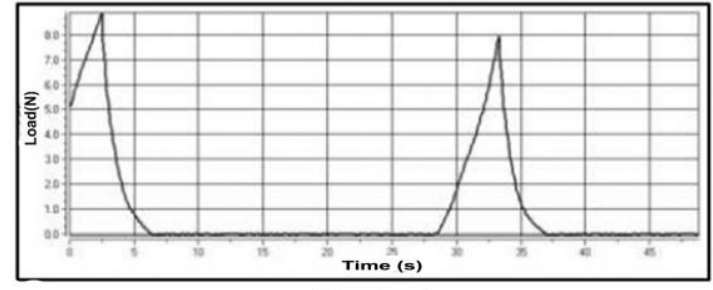

Control

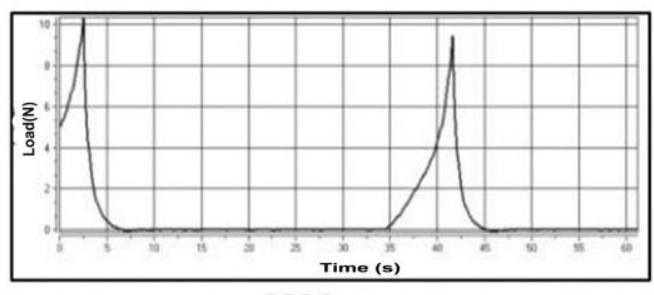

CS20

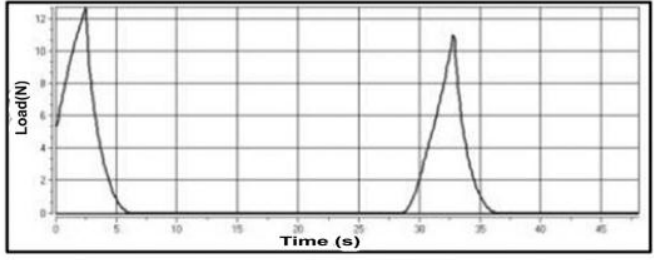

CS60

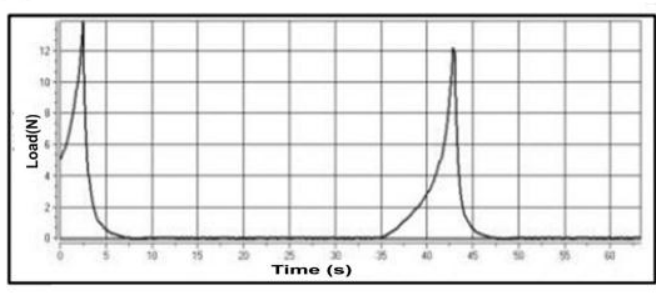

CS40

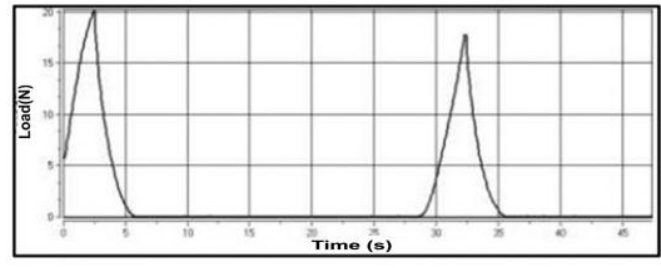

CS80

Fig. (7): Textural profile diagrams of bread crumb samples.

$*$ Control $=100 \%$ wheat flour, CS20 $=20 \%$ corn starch $+80 \%$ wheat flour, CS40 $=40 \%$ corn starch $+60 \%$ wheat flour, CS60 $=60 \%$ corn starch $+40 \%$ wheat flour, CS80 $=80 \%$ corn starch $+20 \%$ wheat flour.

Table (6): Texture profile analysis of bread crumb samples*.

\begin{tabular}{|l|c|c|c|c|c|}
\hline & Control & CS20 & CS40 & CS60 & CS80 \\
\cline { 2 - 6 } Hardness Cycle 1 (N) & 8.85 & 10.31 & 13.85 & 12.66 & 20.16 \\
\hline Hardness Cycle 2 (N) & 7.91 & 9.42 & 12.15 & 10.95 & 17.74 \\
\hline Cohesiveness & 1.06 & 1.38 & 1.29 & 0.74 & 0.54 \\
\hline Adhesiveness (mJ) & 0.1 & 0.1 & 0.3 & 0.2 & 0 \\
\hline Springness (mm) & 2.23 & 2.44 & 2.72 & 3.55 & 4.15 \\
\hline Springness index & 0.45 & 0.49 & 0.55 & 0.71 & 0.83 \\
\hline Chewiness (mJ) & 21 & 34.8 & 48.8 & 33.2 & 45.45 \\
\hline
\end{tabular}

$*$ Control $=100 \%$ wheat flour, CS20 $=20 \%$ corn starch $+80 \%$ wheat flour,

CS $40=40 \%$ corn starch $+60 \%$ wheat flour, CS60 $=60 \%$ corn starch $+40 \%$ wheat flour,

CS80 $=80 \%$ corn starch $+20 \%$ wheat flour. 
Table (7): Correlation coefficients between farinogram parameters and bread crumb digital images properties.

\begin{tabular}{|c|c|c|c|c|c|c|c|c|}
\hline & & $\begin{array}{c}\text { Cell } \\
\text { count }\end{array}$ & $\begin{array}{c}\text { Average } \\
\text { cell Size } \\
(\text { pix })\end{array}$ & $\begin{array}{c}\text { Cells } \\
\text { Area } \\
(\%)\end{array}$ & $\begin{array}{c}\text { Walls } \\
\text { Area } \\
(\%)\end{array}$ & $\begin{array}{c}\text { Min. cell } \\
\text { size } \\
(\text { pix })\end{array}$ & $\begin{array}{l}\text { Max. cell } \\
\text { size } \\
(\text { pix })\end{array}$ & $\begin{array}{l}\text { Cell Size } \\
\text { SD }\end{array}$ \\
\hline $\begin{array}{c}\text { Water } \\
\text { Absorption } \\
(\%)\end{array}$ & $\begin{array}{c}\mathbf{r} \\
\text { p-value }\end{array}$ & $\begin{array}{l}\text { 0.94* } \\
0.017\end{array}$ & $\begin{array}{l}-0.89 * \\
0.042\end{array}$ & $\begin{array}{r}-0.99 * \\
0.017\end{array}$ & $\begin{array}{l}0.99 * \\
0.017\end{array}$ & $\begin{array}{l}\text { 0.00 } \\
\text { NA }\end{array}$ & $\begin{array}{c}0.26 \\
0.676\end{array}$ & $\begin{array}{c}0.56 \\
0.327\end{array}$ \\
\hline $\begin{array}{c}\text { Arrival time } \\
\text { (min.) }\end{array}$ & $\begin{array}{c}\mathbf{r} \\
\text { p-value }\end{array}$ & $\begin{array}{c}\mathbf{0 . 8 2} * * \\
\mathbf{0 . 0 8 8} \\
\end{array}$ & $\begin{array}{l}-\mathbf{- 0 . 8 9 *} \\
0.045\end{array}$ & $\begin{array}{r}-0.93 * \\
0.024\end{array}$ & $\begin{array}{l}0.93 * \\
0.024 \\
\end{array}$ & $\begin{array}{l}\text { 0.00 } \\
\text { NA }\end{array}$ & $\begin{array}{c}0.27 \\
0.662 \\
\end{array}$ & $\begin{array}{c}0.42 \\
0.480 \\
\end{array}$ \\
\hline $\begin{array}{c}\text { Development } \\
\text { time (min.) }\end{array}$ & $\begin{array}{c}\mathbf{r} \\
\text { p-value }\end{array}$ & $\begin{array}{l}0.96 * \\
0.010\end{array}$ & $\begin{array}{c}-\mathbf{- 0 . 8 8} * \\
0.048\end{array}$ & $\begin{array}{l}-0.73 \\
0.158\end{array}$ & $\begin{array}{c}0.73 \\
0.158\end{array}$ & $\begin{array}{l}\text { 0.00 } \\
\text { NA }\end{array}$ & $\begin{array}{l}0.12 \\
0.84\end{array}$ & $\begin{array}{c}0.27 \\
0.657\end{array}$ \\
\hline $\begin{array}{c}\text { Dough } \\
\text { stability } \\
\text { (min.) }\end{array}$ & $\begin{array}{c}\mathbf{r} \\
\text { p-value }\end{array}$ & $\begin{array}{c}-\mathbf{0 . 8 8} * * \\
0.052\end{array}$ & $\begin{array}{l}-0.80 \\
0.102\end{array}$ & $\begin{array}{c}-0.97 * \\
0.005\end{array}$ & $\begin{array}{l}0.97 * \\
0.005\end{array}$ & $\begin{array}{l}\text { 0.00 } \\
\text { NA }\end{array}$ & $\begin{array}{c}0.40 \\
0.500\end{array}$ & $\begin{array}{c}0.67 \\
0.219\end{array}$ \\
\hline $\begin{array}{c}\text { Mixing } \\
\text { tolerance } \\
\text { index ( } \text { B.U.) }\end{array}$ & $\begin{array}{c}\mathbf{r} \\
\text { p-value }\end{array}$ & $\begin{array}{c}-0.92 * \\
0.025\end{array}$ & $\begin{array}{l}0.93 * \\
0.022\end{array}$ & $\begin{array}{l}0.93 * \\
0.021\end{array}$ & $\begin{array}{c}-0.93 * \\
0.021\end{array}$ & $\begin{array}{l}\mathbf{0 . 0 0} \\
\text { NA }\end{array}$ & $\begin{array}{c}-0.23 \\
0.71\end{array}$ & $\begin{array}{l}-0.48 \\
0.219\end{array}$ \\
\hline $\begin{array}{c}\text { Degree of } \\
\text { softening } \\
\text { (B.U.) }\end{array}$ & $\begin{array}{c}\mathbf{r} \\
\text { p-value }\end{array}$ & $\begin{array}{l}-0.91 * \\
0.031\end{array}$ & $\begin{array}{c}0.82 * * \\
0.088\end{array}$ & $\begin{array}{l}0.96 * \\
0.010\end{array}$ & $\begin{array}{c}-0.96 * \\
0.010\end{array}$ & $\begin{array}{l}\mathbf{0 . 0 0} \\
\text { NA }\end{array}$ & $\begin{array}{l}-0.39 \\
0.519\end{array}$ & $\begin{array}{c}-0.693 \\
0.194\end{array}$ \\
\hline
\end{tabular}

* Significant at $95 \%$ level $(\mathbf{p} \leq \mathbf{0 . 0 5})$

** Significant at $90 \%$ level $(\mathbf{p} \leq \mathbf{0 . 1})$

Table (8) shows the extensograph properties as correlated to crumb digital image characteristics. Crumb cell no. was positively correlated to R, E, energy and R/E. Regarding cells area and walls area, they were found to be highly correlated (negatively or positively) with R, R/E and energy. No significant correlations were found between extensograph parameters and the other crumb digital image analysis characteristics.

Pourfarzad et al. (2012) reported that most of the rheological properties of dough have significant effects on crumb digital image characteristics. Bread crumb image analysis characteristics were found to be highly correlated with gluten strength properties evaluated by extensograph (Hovart et al., 2008).

\subsection{Correlation between dough rheological properties and bread crumb textural profile}

When studying the correlation between dough rheological properties by using farinograph, and bread crumb textural properties (Table 9), it was noticed that bread crumb specific volume was strongly correlated with all farinograph properties. The correlation was positive in the case of WA,
AT, DDT andDST, while was negative with DS. A perfect negative correlation coefficient was found between crumb specific volume and MTI.

Hardness, which corresponds in terms of bread quality to the force required to compress a food between the molars, was found to be highly and negatively correlated to WA, AT, and DST, and positively to MTI and DS.This indicates that crumb hardness properties are significantly affected by the farinograph properties. No significant correlations were found between farinograph properties and cohesiveness, adhesiveness and chewiness, except for DDT that was highly correlated with cohesiveness. Singh et al. (2014) concluded that the data observed for chewiness better fitted into a quadratic model rather than into a linear one. This supports our findings regarding the insignificant linear correlation between faringraph properties and chewiness.Springiness index is the ratio of the height the sample springs back after the first compression compared to the maximum deformation. Both springiness and springiness index showed strong correlation with all the studied farinograph parameters. 
Table (8): Correlation coefficients between extensogram parameters and bread crumb digital images properties.

\begin{tabular}{|c|c|c|c|c|c|c|c|c|}
\hline & & $\begin{array}{c}\text { Cell } \\
\text { count }\end{array}$ & $\begin{array}{l}\text { Average } \\
\text { cell Size } \\
\text { (pix) }\end{array}$ & $\begin{array}{c}\text { Cells } \\
\text { Area } \\
(\%)\end{array}$ & $\begin{array}{c}\text { Walls } \\
\text { Area } \\
(\%)\end{array}$ & $\begin{array}{c}\text { Min. cell } \\
\text { size } \\
\text { (pix) }\end{array}$ & $\begin{array}{l}\text { Max. cell } \\
\text { size } \\
(\text { pix })\end{array}$ & $\begin{array}{c}\text { Cell Size } \\
\text { SD }\end{array}$ \\
\hline $\begin{array}{l}\text { Maximum } \\
\text { resistance to } \\
\text { extension "R" } \\
\text { (BU) }\end{array}$ & $\begin{array}{c}\mathbf{r} \\
\text { p-value }\end{array}$ & $\begin{array}{l}0.94 * \\
0.017\end{array}$ & $\begin{array}{c}-0.94 * \\
0.033\end{array}$ & $\begin{array}{r}-0.94 * \\
0.017\end{array}$ & $\begin{array}{l}\text { 0.94* } \\
0.017\end{array}$ & $\begin{array}{l}\text { 0.00 } \\
\text { NA }\end{array}$ & $\begin{array}{c}0.26 \\
0.671\end{array}$ & $\begin{array}{c}0.55 \\
0.336\end{array}$ \\
\hline $\begin{array}{l}\text { Extensibility "E" } \\
(\mathrm{mm})\end{array}$ & $\begin{array}{c}\mathbf{r} \\
\text { p-value }\end{array}$ & $\begin{array}{l}\text { 0.93* } \\
\mathbf{0 . 0 1 7}\end{array}$ & $\begin{array}{l}-0.94 * \\
0.018\end{array}$ & $\begin{array}{l}-0.61 \\
0.270\end{array}$ & $\begin{array}{c}0.61 \\
0.270\end{array}$ & $\begin{array}{l}\mathbf{0 . 0 0} \\
\text { NA }\end{array}$ & $\begin{array}{c}0.27 \\
0.655\end{array}$ & $\begin{array}{l}0.11 \\
0.866\end{array}$ \\
\hline $\begin{array}{l}\text { Proportional } \\
\text { number } \\
(\mathrm{R} / \mathrm{E})\end{array}$ & $\begin{array}{c}\mathbf{r} \\
\text { p-value }\end{array}$ & $\begin{array}{c}0.81 * * \\
0.098\end{array}$ & $\begin{array}{c}-\mathbf{0 . 8 2} * * \\
0.093\end{array}$ & $\begin{array}{c}-0.99 * * \\
0.002\end{array}$ & $\begin{array}{l}0.99 * \\
0.002\end{array}$ & $\begin{array}{l}0.00 \\
\text { NA }\end{array}$ & $\begin{array}{c}0.44 \\
0.445\end{array}$ & $\begin{array}{c}0.61 \\
0.276\end{array}$ \\
\hline Energy $\left(\mathrm{cm}^{2}\right)$ & $\begin{array}{c}\mathbf{r} \\
\text { p-value }\end{array}$ & $\begin{array}{l}0.95^{*} \\
0.015\end{array}$ & $\begin{array}{c}-0.91 * \\
0.034\end{array}$ & $\begin{array}{c}-\mathbf{- 0 . 8 9} * \\
0.042\end{array}$ & $\begin{array}{l}0.89 * \\
0.042\end{array}$ & $\begin{array}{l}\text { 0.00 } \\
\text { NA }\end{array}$ & $\begin{array}{c}0.13 \\
0.883\end{array}$ & $\begin{array}{c}0.44 \\
0.456\end{array}$ \\
\hline
\end{tabular}

* Significant at $95 \%$ level $(\mathrm{p} \leq 0.05)$

** Significant at $90 \%$ level $(\mathrm{p} \leq 0.1)$

Table (9): Correlation coefficients between farinogram parameters and textural properties of bread crumb.

\begin{tabular}{|c|c|c|c|c|c|c|c|c|c|}
\hline & & \multirow{2}{*}{$\begin{array}{l}\text { Crumb } \\
\text { specific } \\
\text { volume } \\
\left(\mathrm{cm}^{3} / \mathrm{g}\right)\end{array}$} & \multicolumn{7}{|c|}{ Texture profile analysis (TPA) } \\
\hline & & & $\begin{array}{c}\text { Hardness } \\
\text { Cycle } 1 \\
\text { (N) }\end{array}$ & $\begin{array}{c}\text { Hardness } \\
\text { Cycle } 2 \\
\text { (N) }\end{array}$ & Cohesiveness & $\begin{array}{l}\text { Adhesiveness } \\
\qquad(\mathrm{mJ})\end{array}$ & $\begin{array}{l}\text { Springness } \\
\quad(\mathrm{mm})\end{array}$ & $\begin{array}{l}\text { Springness } \\
\text { index }\end{array}$ & $\begin{array}{l}\text { Chewiness } \\
\quad(\mathbf{m J})\end{array}$ \\
\hline $\begin{array}{c}\text { Water } \\
\text { Absorption (\%) }\end{array}$ & $\begin{array}{c}\mathbf{r} \\
\text { p-value }\end{array}$ & $\begin{array}{l}0.99 * \\
0.001\end{array}$ & $\begin{array}{c}-0.90 * \\
0.039\end{array}$ & $\begin{array}{l}-0.88 * \\
0.047\end{array}$ & $\begin{array}{c}0.79 \\
0.115\end{array}$ & $\begin{array}{l}-0.21 \\
0.745\end{array}$ & $\begin{array}{c}-0.98^{*} \\
0.002\end{array}$ & $\begin{array}{l}-0.98 * \\
0.002\end{array}$ & $\begin{array}{l}-0.62 \\
0.260\end{array}$ \\
\hline $\begin{array}{l}\text { Arrival time } \\
\quad(\text { min. })\end{array}$ & $\begin{array}{c}\mathbf{r} \\
\text { p-value }\end{array}$ & $\begin{array}{l}0.96 * \\
0.001\end{array}$ & $\begin{array}{c}-0.97 * \\
0.007\end{array}$ & $\begin{array}{c}-0.96 * \\
0.011\end{array}$ & $\begin{array}{c}0.75 \\
0.144\end{array}$ & $\begin{array}{c}0.16 \\
0.801\end{array}$ & $\begin{array}{c}-0.92 * \\
0.025\end{array}$ & $\begin{array}{l}-0.92 * \\
0.023\end{array}$ & $\begin{array}{l}-0.71 \\
0.176\end{array}$ \\
\hline $\begin{array}{l}\text { Development } \\
\text { time (min.) }\end{array}$ & $\begin{array}{c}\mathbf{r} \\
\text { p-value }\end{array}$ & $\begin{array}{l}0.91 * \\
0.032\end{array}$ & $\begin{array}{l}-0.76 \\
0.139\end{array}$ & $\begin{array}{l}-0.74 \\
0.152\end{array}$ & $\begin{array}{l}0.94 * \\
0.016\end{array}$ & $\begin{array}{l}-0.41 \\
0.499\end{array}$ & $\begin{array}{c}-0.97 * \\
0.006\end{array}$ & $\begin{array}{l}-0.97 * \\
0.007\end{array}$ & $\begin{array}{c}0.27 \\
0.654\end{array}$ \\
\hline $\begin{array}{l}\text { Dough stability } \\
\text { (min.) }\end{array}$ & $\begin{array}{c}\mathbf{r} \\
\text { p-value }\end{array}$ & $\begin{array}{l}0.96 * \\
0.011\end{array}$ & $\begin{array}{c}-0.86 * * \\
0.061\end{array}$ & $\begin{array}{c}-0.84 * * \\
0.072\end{array}$ & $\begin{array}{c}0.69 \\
0.201\end{array}$ & $\begin{array}{c}0.03 \\
0.966\end{array}$ & $\begin{array}{c}-0.94 * \\
0.018\end{array}$ & $\begin{array}{l}-0.94 * \\
0.017\end{array}$ & $\begin{array}{c}-0.70 \\
0.18\end{array}$ \\
\hline $\begin{array}{l}\text { Mixing tolerance } \\
\text { index ( B.U.) }\end{array}$ & $\begin{array}{c}\mathbf{r} \\
\text { p-value }\end{array}$ & $\begin{array}{l}-1.0 * \\
0.000\end{array}$ & $\begin{array}{l}0.95 * \\
0.013\end{array}$ & $\begin{array}{l}0.94 * \\
0.018\end{array}$ & $\begin{array}{l}-\mathbf{0 . 8 0} \\
\mathbf{0 . 1 0 3}\end{array}$ & $\begin{array}{l}0.25 \\
0.684\end{array}$ & $\begin{array}{l}0.98 * \\
0.003\end{array}$ & $\begin{array}{l}0.98 * \\
0.003\end{array}$ & $\begin{array}{c}0.65 \\
0.235\end{array}$ \\
\hline $\begin{array}{c}\text { Degree of } \\
\text { softening (B.U.) }\end{array}$ & $\begin{array}{c}\mathbf{r} \\
\text { p-value }\end{array}$ & $\begin{array}{l}-0.97 * \\
0.008\end{array}$ & $\begin{array}{l}0.85 * * \\
0.069\end{array}$ & $\begin{array}{l}0.83 * * \\
\mathbf{0 . 0 7 9}\end{array}$ & $\begin{array}{c}0.68 \\
0.206\end{array}$ & $\begin{array}{c}0.10 \\
0.869\end{array}$ & $\begin{array}{l}0.94 * \\
0.016\end{array}$ & $\begin{array}{l}0.94 * \\
0.016\end{array}$ & $\begin{array}{l}0.675 \\
0.211\end{array}$ \\
\hline
\end{tabular}

* Significant at $95 \%$ level $(\mathrm{p} \leq 0.05)$

** Significant at $90 \%$ level $(\mathrm{p} \leq 0.1)$ 
Regarding the extensograph properties (Table 10 ), perfect or strong correlations were found between extensograph parameters and crumb specific volume.Bread crumb hardness was strongly, but negatively, correlated with all extensograph parameters except for E. As a bread quality attribute, cohesiveness is the strength of internal bonds making up the body ofthe product.E and energy were highly correlated to the cohesiveness. Results also indicated that springiness had a negative correlation with all extensograph parameters.

Nash et al.(2006) reported that the production presented a potential to be good indicators and predictors for the quality characteristics of pan bread crumb. There wasa sufficient evidence to conclude that a significant linear relationship was found between doughrheology and mostof DIA and TPA measurements because the correlation coefficientswere significantly different from zero. It is well established in the literature that gluten affects the rheological properties of dough in two ways, quantity and quality. For our correlation studies, we tried to obtaindoughs with different rheological properties by diluting the gluten using corn starch. This allowed us to make changes to

Table (10): Correlation coefficients between extensogram parameters and textural properties of bread crumb.

\begin{tabular}{|c|c|c|c|c|c|c|c|c|c|}
\hline & & \multirow{2}{*}{$\begin{array}{l}\text { Crumb } \\
\text { specific } \\
\text { volume } \\
\left(\mathrm{cm}^{3} / \mathrm{g}\right)\end{array}$} & \multicolumn{7}{|c|}{ Texture profile analysis (TPA) } \\
\hline & & & $\begin{array}{l}\text { Hardnes } \\
\text { s Cycle } 1 \\
\text { (N) }\end{array}$ & $\begin{array}{c}\text { Hardness } \\
\text { Cycle } 2 \\
\text { (N) }\end{array}$ & Cohesiveness & $\begin{array}{c}\text { Adhesiveness } \\
\qquad(\mathbf{m J})\end{array}$ & $\begin{array}{l}\text { Springness } \\
\quad(\mathbf{m m})\end{array}$ & $\begin{array}{l}\text { Springness } \\
\text { index }\end{array}$ & $\begin{array}{c}\text { Chewiness } \\
(\mathbf{m J})\end{array}$ \\
\hline $\begin{array}{c}\text { Maximum } \\
\text { resistance to } \\
\text { extension " } R \text { " } \\
(B U) \\
\end{array}$ & $\begin{array}{c}\mathbf{r} \\
\text { p-value }\end{array}$ & $\begin{array}{l}1.00 * \\
0.000\end{array}$ & $\begin{array}{c}-0.92 * \\
0.027\end{array}$ & $\begin{array}{r}-0.91 * \\
0.034\end{array}$ & $\begin{array}{c}0.76 \\
0.118\end{array}$ & $\begin{array}{l}-0.23 \\
0.716\end{array}$ & $\begin{array}{c}-0.98 * \\
0.002\end{array}$ & $\begin{array}{c}-0.98 * \\
0.002\end{array}$ & $\begin{array}{l}-0.64 \\
0.242\end{array}$ \\
\hline $\begin{array}{c}\text { Extensibility "E" } \\
(\mathbf{m m})\end{array}$ & $\begin{array}{c}\mathbf{r} \\
\text { p-value }\end{array}$ & $\begin{array}{c}0.86 * * \\
0.064\end{array}$ & $\begin{array}{l}-0.77 \\
0.129\end{array}$ & $\begin{array}{l}-0.76 \\
0.133\end{array}$ & $\begin{array}{l}0.94 * \\
0.017\end{array}$ & $\begin{array}{c}0.65 \\
0.234\end{array}$ & $\begin{array}{c}-0.91 * \\
0.030\end{array}$ & $\begin{array}{c}-0.91 * \\
0.031\end{array}$ & $\begin{array}{l}-0.19 \\
0.756\end{array}$ \\
\hline $\begin{array}{c}\text { Proportional } \\
\text { number } \\
(\mathrm{R} / \mathrm{E})\end{array}$ & $\begin{array}{c}\mathbf{r} \\
\text { p-value }\end{array}$ & $\begin{array}{l}0.96 * \\
0.011\end{array}$ & $\begin{array}{c}-0.93 * \\
0.023\end{array}$ & $\begin{array}{c}-0.91 * \\
0.030\end{array}$ & $\begin{array}{c}0.65 \\
0.234\end{array}$ & $\begin{array}{c}0.00 \\
0.994\end{array}$ & $\begin{array}{c}-0.91 * \\
0.034\end{array}$ & $\begin{array}{c}-0.91 * \\
0.031\end{array}$ & $\begin{array}{l}-0.80 \\
0.108\end{array}$ \\
\hline Energy $\left(\mathrm{cm}^{2}\right)$ & $\begin{array}{c}\mathbf{r} \\
\text { p-value }\end{array}$ & $\begin{array}{l}0.99 * \\
0.002\end{array}$ & $\begin{array}{c}-0.89 * \\
0.046\end{array}$ & $\begin{array}{c}-0.87 * * \\
0.059\end{array}$ & $\begin{array}{c}0.86 * * \\
0.059\end{array}$ & $\begin{array}{c}0.25 \\
0.683\end{array}$ & $\begin{array}{c}-0.99 * \\
0.000\end{array}$ & $\begin{array}{c}-1.00 * \\
0.000\end{array}$ & $\begin{array}{l}-0.54 \\
0.352\end{array}$ \\
\hline
\end{tabular}

* Significant at 95\% level $(\mathrm{p} \leq 0.05)$

** Significant at $90 \%$ level $(\mathrm{p} \leq 0.1)$

of higher volume bread requires the use of high extensibility dough. Dough high extensibility leads to the stability of gas cells within gluten network and the opposite is true (Lagrain et al., 2012). Elasticity of the dough could be a result of the interaction between gelatinized starch and gluten and contribute in the formation of continuous sponge structure of bread, and thus has a significant role in forming the textural properties of bread (Chin and Martin, 2014).

\section{Conclusion}

Dough rheological properties and their association with both digital image analysis (DIA) and texture profile analysis (TPA)characteristics gluten quantity while maintaining the gluten quality (as per $\mathrm{g}$ of gluten).The obtained results will be of importance to scientists and bread technologist in their selection of the appropriate flour type for their products, and to predict the quality characteristics of bread. Future studies could investigate the effects of other factors such as bread improvers, non-wheat flours, and processing conditions on dough rheology and their correlation with bread crumb quality.

\section{REFERENCES}

A.A.C.C. (2010). Approved Methods of Analysis of AACC International, $11^{\text {th }}$ ed., St. Paul, Minnesota, USA. 
Abang Zaidel D.N., Chin N.L. and Yusof Y.A (2010). A review on rheological properties and measurements of dough and gluten. J. Appl. Sci., 10: 2478-2490.

Ammar M.S., Hegazy A.E. and Bedeir S.H. (2009). Using of taro flour as partial substitute of wheat flour in bread making. World J. Dairy Sci., 4: 94-99.

Angioloni A. and Collar C. (2009). Bread crumb quality assessment: a plural physical approach. Europ. Food Res. Tech., 229: 2130.

Autio K., Flander L., Kinnunen A. and Heinonen R. (2001). Bread quality relationship with rheological measurements of wheat flour. Cereal Chem., 78: 654-657.

Chen R.Y., Seabourn B.W., Xie F. and Herald T.J. (2009). A modified extensigraph method for evaluating dough properties of hard wheat breeding lines. Cereal Chem., 86: 582-589.

Chin N.L. and Martin P.J. (2014). Rheology of bread and other bakery products. In: Bakery products science and technology. R. Zhou (Ed.) pp. 453 -472. John Wiley \& Sons, Ltd. West Sussex, UK.

Cubadda R., Carcea M. and Pasqui L.A. (1992). Suitability of the gluten index method for assessing gluten strength in durum wheat and semolina. Cereal Foods World, 37: 866869.

Defloor I., Nys M. and Delcour J. (1993). Wheat starch, cassava starch, and cassava flour impairment of the breadmaking potential of wheat flour. Cereal Chem. 70: 526-530.

Dobraszczyk B.J. (2003). The physics of baking: rheological and polymer molecular structure-function relationships in braed making. Polish J. Food and Nutr. Sciences, 12: 24-31.

Farrera-Rebollo R.R., Salgado-Cruz M.P., Chanona-Pérez J.J., Gutiérrez-Lopéz G.F., Allamilla-Beltrán L. and CalderónDomíguez G. (2012). Evaluation of image analysis tool for characterization of sweet bread crumb structure. Food and Bioproc. Tech., 5: 474-484.

Feili R., Zman W., Abdullah W.N.W. and Yang T.A. (2013). Physical and sensory analysis of high fiber bread incorporated with jackfruit rind flour. Food Sci. Techn., 2: 3036.
Hovart D., Magdić D., ŠimićG., Dvojković K. and Drezner G. (2008). The relation between dough rheology and bread crumb peoperties in winter wheat. Agric. Consp. Sci., 73: 912.

Lagrain B., Boeckx L., Wilderjans E., Delcour J.A and Lauriks W. (2006). Non-contact ultrasound characterization of bread crumb: Application of Biot-Allard model. Food Res. Int'l. 39: 1067-1075.

Lagrain B., Wilderjans E., Glorieux C. and Delcour J. (2012). Importance of gluten and starch for structural and textural properties of crumb from fresh and stored bread. Food Biophys., 7, 173-181.

Magdić D., Horvat D., Drezner G., Jurković Z. and Šimić G. (2006). Image analysis of bread crumb structure in relation to gluten strength of wheat. Poljoprivred (Agriculture), 12: 5862.

McCann T.H., Le Gall M. and Day L. (2016). Extensional dough rheology- Impact of flour composition and extension speed. J. Cereal Sci., 69: 228-237.

Nash D., Lanning S.P., Fox P., Martin J.M., Blake N.K., Souza E., Graybosch R.A., Giroux M.J. and Talbert L.E. (2006). Relationship of dough extensisbility to dough strength in spring wheat cross. Cereal Chem. 83, 255256.

Nindjin C., Amani G.N. and Sindic M. (2011). Effect of blend levels as composite wheat dough performance made from yam and cassava native starches and bread quality. Carbohydrate Polymers, 86: 1637-1645.

Pa N.F.C., Chin N.L., Yusof Y.A. and Abdul Aziz N. (2013). Measurement of bread crumb texture via imaging of its characteristics. J. Food, Agric. \& Environ., 11: 48-55.

Perten H. (1990). Rapid measurement of wet gluten by the gluten index. Cereal Foods World, 35: 401-402.

Pourfarzad A., Mohebbi M. and MazahaeriTehrani M. (2012). Interrelationship between image, dough and barabari bread characteristics; use of image analysis to predict rheology, quality and shelf life. Int'1. J. Food Sci. Tech., 47: 1354-1360.

Sapirstein H. D. (1999). The imaging and measurement of bubbles in bread. In: Bubbles in food, G. M. Campbell, C. 
Webb, \& S.S. Pandiella (Eds.), pp. 233-243. American Association of Cereal Chemists, St. Paul, Minnesota, USA.

Sapirstein H.D., Roller R. and Bushuk W. (1994). Instrumental measurement of bread crumb grain by digital image analysis. Cereal Chemi., 71: 383-391.

SAS (1987). SAS property software. Statistical Analysis Institute Inc., Cary, North Carolina, USA.

Scanlon M. G. and Zghal M. C. (2001). Bread properties and crumb structure. Food Res. Int'1., 34: 841-864.

Scheuer P.M., Ferreira J.A.S., Mattioni B., Miranda M.Z. and Francisco A. (2015). Optimization of image analysis technique for quality assessment of whole-wheat bread with fat replacer. Food Sci. Tech., 35: 133142.

Schiraldi A. and Fessas D. (2000). Mechanism of staling. In: Bread staling, C. Pavinee, \&Y.Vodovotz (Eds.), pp. 2-10. CRC Press, New York, USA..

Singh N., Jha A., Chaudhary A. and Upadhyay A. (2014). Enhancement of the functionality of bread by incorporation of shatavari (Asparagus racemosus).J. Food Sci., Techn. 51: 2038-2045.

Švec I. and Hrušková M. (2004). Image data of crumb structure of bread from flour of Czech spring wheat cultivars. Czech J. of Food Sci., 22, 133-142.

Tietze S., Jekle M. and Becker T. (2016). Possibilities to derive empirical dough characteristics from fundamental rheology. Trends in Food Sci. \& Tech. 57A: 1-10.
Upadhyay R., Ghosal D. and Mehra A. (2012). Characterization of bread dough: rheological properties and microstructure. J. Food Eng., 109: 104-113.

Uthayakumaran S., Newberry M., Phan-Thien N. and Tanner R. (2002). Small and large strain rheology of wheat gluten. Rheol. Acta, 41: 162-171.

Villarino C.B.J., Jayasena V., Coorey R., Chakrabarti-Bell S. and Johnson S. (2015). Optimization of formulation and process of Australian sweet lupin (ASL)-wheat bread. LWT-Food Sci. and Tech., 61: 359-367.

Wang J., Rosell C.M. and Benedito de Barber C. (2002). Effect of the addition of different fibers on wheat dough performance and bread quality. Food Chemi., 79: 221-226.

Yesli A., Latati M., Tellah S., Abdellaoui Z. and Ounane G. (2017). Physiochemical and rheological properties and bread making potential of durum flour and semolina. J. Food, Agric. \& Environ. 15: 14-20.

Zghal M.C., Scanlon M.G. and Sapirstein H.D. (1999). Prediction of bread crumb density by digital image analysis. Cereal Chem., 76: 734-742.

Zghal M.C., Scanlon M.G. and Sapirstein H.D. (2001). Effect of flour strength baking absorption, and processing conditions on the structure and mechanical properties of bread crumb. Cereal Chem. 78: 1-7.

Zou K.H., Tuncali K. and Silverman S.G. (2003).Correlation and simple linear regression. Radiol. 227: 617-622. 


\section{العلاقة بين الخصائص الريولوجية للعجين و صفات جودة اللبابة لخبز القالب \\ مختار حرب عبد الخالق - محمد رشاد جودة يوسف

$$
\text { معهد بحوث تكنولوجيا الأغذية ـ-مركز البحوث الزراعية ـ الجيزة ـ مصر }
$$

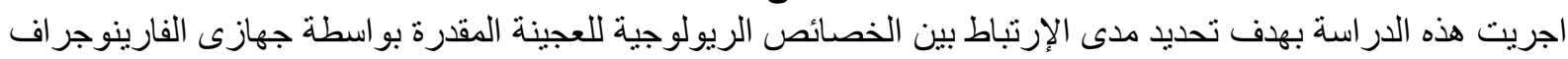

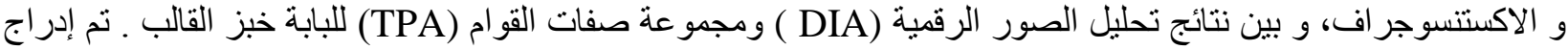



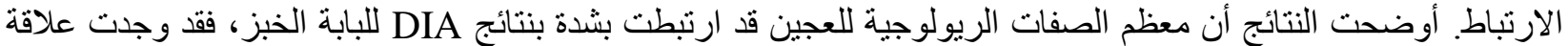
وثيقة ( سواء موجبة أو سالبة) بين قياسات جهاز الفارينوجر اف وبين كل من عدد خلايا اللبابة و منوسط حجمها و و مساحتها



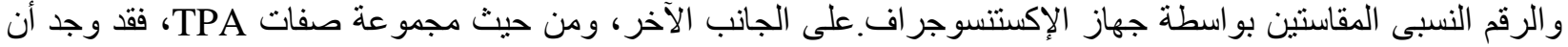

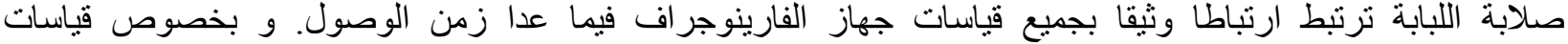

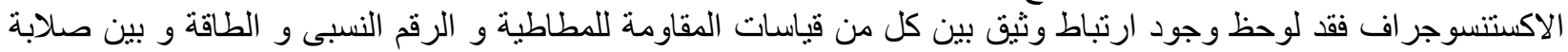

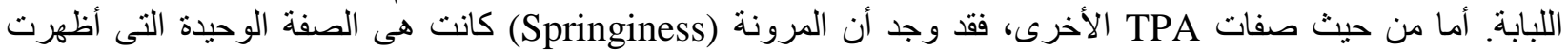

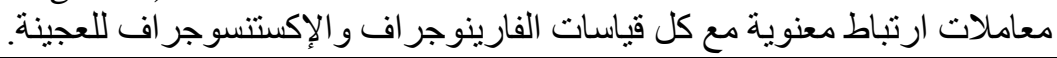
المجلة العلمية لكلية الزراعة - جامعة القاهرة- المجلد (69) العدد الرابع (أكتوبر 2018) 